\section{Permisive Parenting and Extrovert Personality With Consumtive Behavior in Indonesian Workers (TKI / TKW) Children in Bandung Tulungagung District}

Malik Maya Faisati; IGAA. Noviekayati; Amanda Pasca Rini

Universitas 17 Agustus 1945 Surabaya

e-mail: faisatimaya@gmail.com
Journal PSIKODIMENSIA

Volume 17, No. 2, Juli - Desember 2018

ISSN cetak : 1411-6073

ISSN online : 2579-6321

DOI 10.24167/psidim.v17i2.1521

\begin{abstract}
The purpose of this study was to examine the relationship between permissive parenting and extroverted personality with consumptive behavior in TKI / TKW children in Bandung Tulungagung District. The research subjects were 70 students of class X and XI of SMK Negeri 1 Bandung Tulungagung. The research method uses Quantitative by using Non-Parametric Kendall analysis. Based on the analysis, it was obtained results that permissive parenting and extroverted personality with consumptive behavior had a significant correlation. Extroverted personality with consumptive behavior has a significant relationship, but permissive parenting with consumptive behavior is not significantly associated.
\end{abstract}

Keywods: Consumptive Behavior, Permissive Parenting, Extroverted Personality

\section{PENDAHULUAN}

Menurut data terbaru dari PUSLITFO BNP2TKI pada tahun 2016 Kabupaten Tulungagung merupakan menjadi peringkat ke-12 dari 355 kabupaten/kota sebagai salah satu kota penyumbang TKI/TKW, sedangkan di Propinsi Jawa Timur Kabupaten Tulungagung berada di peringkat 3 setelah kabupaten Ponorogo dan Kabupaten Blitar. Banyak warga Tulungagung di usia produktif yang memilih menjadi pahlawan devisa, dengan harapan mendapatkan penghasilan yang lebih menggiurkan dari pada bekerja di daerah tempat tinggalnya. Bekerja sebagai TKI/TKW di negara lain menjadikan para orang tua memilih untuk hidup berjauhan dengan anak-anaknya. Terdapat banyak dampak yang ditimbulkan dari konsekuensi bekerja sebagai TKI/TKW, terutama dalam perkembangan anak yang ditinggalkannya.
Berdasarkan tingkat perekonomian orang tua yang maningkat, maka perilaku konsumtif juga berdampak pada perilaku anakanak mereka, terutama pada anak usia remaja. Usia remaja menjadikan anakanak memiliki keinginan yang lebih besar dalam memenuhi keinginannya dari pada kebutuhannya. Kebiasaan yang dilakukan oleh anak- anak yang ditinggal pergi sebagai TKI/TKW, antara lain: mereka menjadi memiliki banyak keinginan yang harus dikabulkan oleh orang tua. Banyaknya permintaan yang dilakukan oleh anak-anak merupakan bentuk protes dari kurangnya perhatian dan kasih sayang dari peran seorang ayah dan peran ibu.

Menururt Lubis (1987) perilaku konsumtif adalah kebiasaan mengkonsumsi barang atau jasa, tanpa didasarkan pada pertimbangan yang rasional melainkan karena adanya keinginan yang harus mencapai hingga 
pada taraf yang tidak rasional lagi untuk mendapatkannya. Sumartono (2002), berpendapat bahwa perilaku konsumtif merupakan tindakan seorang membeli suatu barang tanpa adanya pertimbangan yang masuk akal dimana seorang tersebut dalam membeli suatu barang tidak didasarkan pada faktor kebutuhan. Sedangkan menurut Schiffman dan Kanuk (2004, dalam Widyaningrum, 2016) Perilaku konsumtif biasanya dipengaruhi oleh motif emosional tidak mempertimbangkan apakah barang yang dibelinya sesuai dengan dirinya, sesuai dengan kebutuhannya, sesuai dengan kemampuannya dan sesuai dengan standar atau kualitas yang diharapkannya. Jadi, dapat disimpulkan bahwa perilaku konsumtif merupakan kegiatan mengkonsumsi barang atau jasa yang tidak terlalu diperlukan dengan tujuan memenuhi keinginan atau kesenangan untuk mencari kepuasan, kesenangan fisik atau hanya mencoba sesuatu yang baru, bukan didasari oleh faktor pemenuhan kebutuhan.

Berdasarkan urian yang telah dijelaskan di atas, terdapat beberapa faktor yang mempengaruhi perilaku konsumtif anak yang ditinggal bekerja sebagai TKI/TKW di luar negeri, yaitu pola asuh permisif dan kepribadian ektrovert. Demi memenuhi keadaan ekonomi yang serba cukup, orang tua memilih untuk bekerja ke luar negeri dengan resiko hidup berjauhan dengan anak. Keadaan ini berakibat bahwa orang tua kurang dapat memberikan kasih sayang yang penuh terhadap anak. Kasih sayang yang diberikan lebih banyak dalam bentuk materi. Bagi sebagian orang tua, pemenuhan akan kebutuhan dan keinginan anak merupakan bentuk kasih sayang yang dapat menggantikan kehadirannya di kehidupan anak. Akan tetapi kebiasaan seperti ini, tanpa adanya pengawasan dari orang yang lebih tua, menjadikan anak terbiasa memenuhi semua keinginannya dan anak berdampak menjadi konsumtif terhadap aktifitas mengkonsumsi barang atau jasa berdasarkan keinginannya dari pada sesuai dengan kebutuhannya.

Terdapatnya perasaan bersalah yang dimiliki oleh orang tua yang meninggalkan anaknya untuk bekerja sebagai TKI/TKW, menjadikan orang tua memiliki cara tersendiri untuk menebus rasa bersalahnya, yaitu berusaha memanjakan anak dengan materi, sehingga cenderung untuk mengabulkan semua keinginan anak tanpa adanya pertimbangan dalam kegunaan terhadap pemenuhan kebutuhan itu. Misanya: anak masih berada di usia sekolah dasar dan memiliki gadget model terbaru atau anak meminta laptop di usianya, hal ini menjadikan anak terbiasa mendapatkan barang mewah, sehingga anak akan terbiasa menjadi konsumtif dalam kehidupan sehari-hari.

Tipe pola asuh yang permisif dapat membentuk anak menjadi berperilaku konsumtif dapat dilihat dari tipe kepribadian, Individu yang memiliki kepribadian esktrovert memiliki beberapa ciri, diantranya adalah keterbukaan, mudah pergaulan, ramah, penggembira, tertarik berinteraksi dengan lingkungannya, mudah mempengaruhi dan juga mudah dipengaruhi. Tipe kepribadian Ekstrovert memiliki kecenderungan untuk berperilaku konsumtif dari pada tipe kepribadian introvert. Anak yang memiliki kepribadian ekstrovert memiliki kecenderungan lebih terbuka terhadap lingkungannya, sehingga anak yang memiliki kepribadian ekstrovert akan lebih mudah terpengaruhi dengan kebiasaan yang ada dilingkungannya.

Menurut Mangkunegara (2009) menyebutkan bahwa ada dua (2) faktor yang mempengaruhi perilaku konsumtif seseorang, yaitu kekuatan sosial budaya dan kekuatan psikologis. Salah satu kekuatan psikologis yaitu kepribadian 
karena kepribadian dapat mempengaruhi kecenderungan perilaku seorang individu. Faktor kepribadian merupakan faktor bawaan yang melekat yang dipengaruhi oleh faktor genetik dan lingkungan.

Terutama pada usia remaja, para anak TKI/TKW ini memilik kecenderungan untuk memiliki bendabenda yang sama dengan temantemannya, mereka cenderung bertingkah laku yang sama, dan memiliki hobi yang sama dengan teman-temannya. Misalnya, ketika ada salah satu remaja cewek yang memiliki jilbab model terbaru, maka beberapa temannya juga akan membeli jilbab model terbaru itu. Begitu juga dengan remaja laki-laki, ketika ada teman yang memakai minyak rambut yang terlihat keren, maka mereka juga akan membeli merk yang sama dengan temannya tersebut.

Salah satu tanda yang memiliki kecenderungan berkepribadian ekstrovert adalah keinginan untuk dapat diakui di lingkungan pertemanan, sehingga menjadikan anak ikut-ikutan terhadap perilaku yang dilakukan oleh teman-temannya. Misalnya, ketika ada teman-teman yang setelah pulang sekolah nongkrong di suatu cafe atau tempat yang menarik, maka kegiatan itu akan diikuti oleh teman-teman yang lainnya. Beberapa dari mereka akan lebih banyak berlomba-lomba untuk memiliki gadget, kamera dan beberapa barang model terbaru dengan meminta beberapa kiriman barang dari luar negeri.

Hipotesis yang disampaikan dalam penelitian ini adalah korelasi antara kecenderungan pola asuh permisif dengan perilaku konsumtif. Kedua ada korelasi antara kecenderungan kepribadian ektrovert terhadap perilaku konsumtif.

\section{METODE}

Penelitian menggunakan sampel sebanyak 70 siswa yang diambil secara acak dengan proses penyaringan yang telah dilakukan berdasarkan identitas siswa yang memiliki orang tua yang bekerja ke luar negeri baik dari kelas $\mathrm{X}$ maupun XI.

Skala kepribadian ekstrovert diperoleh koefisien relibilitas sebesar 0,791, hasil dari reliabilitas Alpha Skala Pola asuh konsumtif diperoleh koefisien relibilitas sebesar 0,847, dan hasil dari reliabilitas Alpha Skala kepribadian ekstrovert diperoleh koefisien relibilitas sebesar 0,904 , sehingga hasil skala yang diperoleh lebih besar dari batas minimun koefisiensi relibilitas 0,700.

Hasil uji normalitas menggunakan koofesien kolmogrov-smirnov test memiliki sebaran skor yang normal, dengan hasil $\mathrm{Z}=0,828$ pada $\mathrm{p}=0,500$ untuk variabel perilaku konsumtif, koofesien kolmogrov-smirnov test $\mathrm{Z}=$ 0,577 pada $\mathrm{p}=0,893$ untuk variabel pola asuh permisif dan koofesien kolmogrovsmirnov test $\mathrm{Z}=0,854$ pada $\mathrm{p}=0,459$ untuk variabel kepribadian ekstrovert. Berdasarkan uji linieritas pola asuh permisif terhadap perilaku konsumtif memperoleh F 23,922 dengan P 0,000, sehingga $\mathrm{P}<0,05$ maka dianggap linier. Sedangkan kepribadian ekstrovert terhadap perilaku konsumtif memperoleh $F$ 0,642 dengan $P$ 0,426, karena $\mathrm{P}>0,05$ maka dianggap tidak linier.

\section{HASIL}

Berdasarkan hasil uji analisis Non-Parametrik Kendall terhadap variabel pola asuh permisif dan variabel kepribadian ekstrovert dengan variabel perilaku konsumtif, antara lain: 
Tabel 1. Hasil Analisis

\begin{tabular}{clccc}
\hline No & \multicolumn{1}{c}{ Variabael } & Koefosiensi & Signifikan & Keterangan \\
\hline 1 & $\begin{array}{l}\text { Pola asuh permisif } \\
\text { perilaku konsumtif }\end{array}$ & 0,014 & 0.317 & $\begin{array}{c}\text { Tidak signifikan } \\
(\mathrm{p}>0,05)\end{array}$ \\
\hline 2 & $\begin{array}{l}\text { Kepribadian ekstrovert terhadap } \\
\text { pola asuh permisif }\end{array}$ & 1,000 & 0.000 & $\begin{array}{c}\text { Sangat signifikan } \\
(\mathrm{p}<0,01)\end{array}$ \\
\hline
\end{tabular}

Hasil analisis menunjukkan bahwa hipotesis pertama berdasarkan uji analisis Non-Parametrik Kendal diketahui bahwa dengan $\mathrm{n}=70$, dan nilai signifikansi adalah 0.317 , yang berarti lebih dari $0,05(\mathrm{p}>0,05)$ hasil dari koefosiensi sebesar 0,014 , hal ini menunjukkan bahwa tidak ada hubungan yang signifikan antara pola asuh permisif terhadap perilaku konsumtif pada anak TKI/TKW di kecamatan Bandung Tulungagung.

Untuk hipotesis kedua, berdasarkan uji analisis Non-Parametrik Kendal diketahui bahwa, N (jumlah data) adalah 70, dengan nilai signifikansi adalah 0,00 , yang berarti kurang dari 0,05 $(\mathrm{p}>0,05)$ hasil dari koefosiensi sebesar 1,000. Hal ini menunjukkan bahwa ada hubungan yang tinggi antara kepribadian ekstrovert terhadap perilaku konsumtif pada anak TKI/TKW di kecamatan Bandung Tulungagung.

\section{DISKUSI}

Berdasarkan dari hasil analisis data dengan menggunakan analisis NonParametrik Kendall diketahui bahwa terdapat korelasi yang negatif antara pola asuh permisif dengan perilaku konsumtif pada anak TKI/TKW di kecamatan Bandung Tulungagung. Hal ini menunjukkan bahwa faktor pola asuh yang permisif ternyata tidak memiliki hubungan dalam mempengaruhi perilaku konsumtif pada anak usia remaja yang ditinggal bekerja oleh orang tua sebagai TKI/TKW. Jadi dapat diartikan bahwa perilaku konsumtif pada anak TKI/TKW tidak didukung oleh faktor pola asuh permisif yang didapat dari perlakuann orang tua, karena orang tua cenderung melakukan pola asuh yang demokratis dan otoriter.

Anak pada usia remaja yang memiliki bergaya hidup konsumtif, akan berusaha membelanjakan uangnya hanya untuk menjaga gengsi dalam pergaulan, baik berbentuk suatu barang maupun jasa yang dipakai oleh para anak remaja. Para anak remaja tidak memperdulikan apakah barang yang beli itu merupakan barang kebutuhan atau hanya barang untuk mencapai kepuasan dan keinginannya. Menurut Fromm (1955) perilaku konsumtif dimana keadaan ingin membeli atau mengkonsumsi yang terus meningkat, demi mendapatkan kepuasan dalam hal kepemilikan barang dan jasa tanpa mempedulikan kegunaan. Keinginan membeli suatu hal yang sedang up to date, banyak dan bagus, didasari pada tujuan menunjukkan status, prestige, kekayaan, keistimewaan dan sesuatu yang mencolok, tanpa mempertimbangkan fungsinya.

Menurut data yang diperoleh bahwa perilaku yang ditunjukkan oleh subjek para anak TKI/TKW di kecamatan Tulungagung memiliki sikap kecenderungan dalam berperilaku konsumtif. Para anak TKI/TKW yang memiliki kecenderungan dalam berperilaku konsumtif sebanyak 30\% dari total sampel dan $70 \%$ sampel yang lainnya tidak menunjukkan adanya perilaku konsumtif. Kecenderungan yang dimiliki oleh anak- anak TKI/TKW untuk berperilaku konsumtif, merupakan dampak dari lingkungan pertemanan yang lebih banyak mempengaruhi. 
Hal ini dikarenakan banyaknya dampak yang terjadi dari pola asuh permisif. Orang tua dengan model pola asuh permisif dengan mendidik anak tanpa batasan-batasan yang jelas terhadap peraturan. Pola pengasuhan seperti ini akan mejadikan anak cenderung tidak memiliki kepedulian dengan nilai-nilai/aturan-aturan yang ada keluarga maupun dimasyarakat atau cenderung semaunya sendiri tanpa adanya pengendalian terhadap keinginannya. Sehingga pola asuh permisif mengakibatkan remaja cenderung merasa bebas, tanpa ada aturan dari orang tua. Pola asuh permisif cenderung memberi kebebasan terhadap anak untuk berbuat apa saja ternyata sangat tidak kondusif bagi pembentukan karakter terhadap. Penerapan pola asuh permisif dapat menyebabkan anak pada usia remaja tidak mempunyai kontrol diri yang baik dan tidak dapat berkomunikasi dengan baik dengan keluarganya, terutama orang tua.

Menurut Harlock (dalam Yusuf:2017) menyatakan bahwa dampak dari perilaku anak yang didapat dari pola asuh orang tua, antara lain: anak menjadi cenderung impulsif dan agresif terhadap sesuatu yang tidak sesuai dengan keinginannya, Suka memberontak karena jarang mendapatkan arahan dari orang tua. Kurangnya rasa percaya diri yang dimilik, ada kecenderungan untuk mendominasi lawan bicaranya atau lingkungannya, tidak memiliki keinginan untuk berprestasi dan tidak jelas arah hidupnya. Sehingga faktor pola asuh permisif dengan perilaku konsumtif tidak ada korelasi yang signifikan terhadap kedua variabel tersebut. Hal ini menunjukkan bahwa pola asuh permisif kurang dapat mendominasi perilaku konsumtif pada anak remaja yang ditinggal oleh orang tuanya bekerja sebagai TKI/TKW di luar negeri, akan tetapi lebih mempengaruhi remaja dalam hal sosial dan akademik, karena kurang adanya pengawasan dari orangtua.

Penelitian yang telah dilakukan oleh Pravitasari (2012) dalam Pengaruh Persepsi Pola Asuh permisif orang tua terhadap perilaku membolos, terdapat hubungan yang signifikan antara pola asuh permisif denga perilaku membolos yang dilakukam anak SMK. Menurut penelitian yang dilakukan oleh Rahman (2015) dalam hubungan antara pola asuh permisif orangtua dan kecerdasan emosional siswa dengan hasil belajar matematika siswa SMP di kabupaten Enrekang yang menunjukkan bahwa terdapat hubungan yang positif antara pola asuh permisif orangtua dan kecerdasan emosional siswa dengan hasil belajar. Berdasarkan penelitian yang telah dilakukan oleh Intan Sari menyatakan bahwa tidak ada hubungan yang signifikan antara persepsi pola asuh orang tua terhadap perilaku konsumtif pada remaja usia 18-21 tahun di Jakarta. Hal ini dikarenakan banyak faktor yang lebih mempengaruhinya, antara lain peran konformitas terhadap teman sebaya agar dapat diterima dalam kelompok teman sebayanya dan konsep diri yang dimiliki oleh para remaja. Semakin tinggi konsep diri yang di miliki maka semakin tinggi pula perilaku konsumtifnya, begitu pula sebaliknya. Hal ini didukung dengan hasil analisis yang telah dilakukan oleh peneliti, bahwa pola asuh permisif dengan perilaku konsumtif pada anakanak TKI/TKW tidak memiliki korelasi secara signifikan.

Hal ini dikarenakan terdapat faktor lain yang mempengaruhi perilaku konsumtif pada anak remaja yang ditinggal oleh orang tuanya bekerja menjadi TKI/TKW. Mereka menjadi lebih mendahulukan kepentingan atau gagasan ide yang dimiliki oleh temanteman sebayanya dari pada mendengarkan aturan yang dibuat oleh keluarganya. Para remaja memiliki 
kecenderungan untuk dapat diterima di kelompok pertemananya, sehingga mereka akan berusaha untuk melakukan kegiatan yang biasa dilakukan oleh teman sebayanya. Berdasarkan penelitian yang dilakukan oleh Hotpascaman (2008) bahwa ada korelasi yang signifikan antara perilaku konsumtif dengan konformitas didasarkan pada pengaruh normalitas. selain konformitas yang dimiliki oleh remaja, berdasarkan peenelitian yang dilakukan oleh Eva Suminar (2015) terdapat konsep diri yang memiliki korelasi signifikan dengan perilaku konsumtif pada remaja di Pasuruhan.

Berdasarkan data deskriptif yang telah disajikan diatas bahwa pola asuh permisif dengan perilaku konsumtif terdapat hubungan yang tidak signifikan. Selain hasil yang tidak signifikan terdapat beberapa sebaran kriteria, antara lain: banyaknya sampel berada dikategori sedang sehingga rata-rata orang tua yang menggunakan pola asuh yang tidak konsisten, terkadang permisif, terkadang otoriter, atau cenderung demokratis, Akan tetapi terdapat 3 subjek yang berada di kategori sangat tinggi dan 12 lainya berada di kecenderungan dalam pola asuh permisif.

Terdapat faktor yang dapat mempengaruhi perilaku konsumtif pada anak TKI/TKW di Kecamatan Bandung Tulungagung, yaitu Kepribadian Ekstrovert. Terdapat korelasi yang signifikan terhadap faktor kepribadian ekstrovert dengan perilaku konsumtif. Hal ini menunjukkan bahwa semakin tinggi kepribadian ekstrovert yang dimiliki, maka semakin tinggi pula prilaku konsumtif yang dimiliki oleh para anak TKI/TKW. Diartikan bahwa Anak yang ditinggal bekerja oleh orang tua menjadi TKI/TKW yang memiliki keterbukaan terhadap lingkungannya atau berkepribadian ekstrovert dapat mempengaruhi perilaku konsumtif yang diperoleh dari lingkungannya, terutama kelompok pertemanannya. Hal ini terjadi karena perilaku konsumtif lebih banyak disebabkan dari respon lingkungan sekitar terhadap para anak TKI/TKW. Para anak TKI/TKW memiliki penguat untuk melakukan perilaku konsumtif, karena memiliki role model dengan kecenderungan mengulang perilaku yang disukai.

Kepribadian ekstrovert menurut Eysenck (Alwisol, 2008) merupakan adanya kecenderungan untuk lebih tertarik menjalin hubungan dengan lingkungannya merupakan salah satu karakteristik dari kepribadian ekstrovet. Karakter kepribadian ini dapat dilihat dari bagaimana anak remaja dalam menjalin hubungan dengan lingkungan pertemanannya, terutama dalam menjalin hubungan dengan lingkungan pertemanan yang baru. Keterbukaan yang dimiliki oleh anak TKI/TKW terhadap lingkungan mampu mempengaruhi perilaku konsumtif, sehingga para anak TKI/TKW memiliki kecenderungan untuk melakukan sesuatu yang seperti dilakukan oleh lingkungan sekitarnya, terutama yang dilakukan oleh kebanyakan teman-temannya. Karena bagi sebagian besar anak yang ditinggal bekerja orang tuanya sebagai TKI/TKW, mereka memiliki role model dari teman-temannya dari pada orang tua. Misalnya, banyak teman-teman yang sering nongkrong disuatu cafe atau tempat wisata, maka mereka juga akan melakukan hal yang sama. Begitu pula, ketika mulai ada tren fashion terbaru maka mereka juga tidak ingin ketinggalan untuk dapat berpenampilan keren.

Para remaja yang memiliki kepribadian ekstrovert dengan perilaku konsumtif adalah perilaku yamg ingin diakui oleh teman sebayanya seperti dalam penelitian yang dilakukan oleh Sandra Widyaningrung (2016) menyatakan bahwa terdapat korelasi 
yang signifikan terhadap perbedaan kepribadian ekstrovert dengan perilaku konsumtif dengan siswa yang bertipe kepribadian introvert. Hal ini dapat diartikan bahwa adanya kecenderungan perilaku konsumtif pada siswa SMA kelas XI yang memiliki tipe kepribadian ekstrovert lebih tinggi daripada siswa yang memiliki tipe kepribadian introvert. Sehingga terdapat hubungan antara faktor kepribadian ekstrovet dengan perilaku konsumtif pada anakanak yang ditinggal pergi oleh orang tuanya untuk bekerja sebagai TKI/TKW di Kecamatan Bandung Tulungagung.

\section{Eysenck}

(Atkinson,1993)

mengemukakan bahwa seseorang yang mempunyai tipe kecenderungan ekstrovert akan memiliki karakteristik sebagai berikut: suka bergaul, menyukai pesta, memiliki banyak teman, selalu membutuhkan teman untuk diajak berbicara, tertarik dengan apa yang terjadi disekitar mereka, membandingka pendapat mereka dengan pendapat orang lain seperti aksi dan inisiatif, mudah mendapat teman dan beradaptasi dalam kelompok baru. Berdasarkan beberapa karakteristik yang telah dikemukakan oleh Eysenck, para anak TKI/TKW memiliki kemampuan untuk mudah bergaul dengan lingkungannya, mereka mudah beradaptasi terhadap lingkungan yang baru dan memiliki banyak teman. Akan tetapi ketika mereka terlalu mudah untuk membuka diri terhadap lingkungannya, beberapa dari mereka tidak dapat mempertahankan jati diri yang dimilikinya. Para anak TKI/TKW akan mudah terbawa oleh arus perubahan zaman yang dilakukan oleh lingkungan pertemanannya, sehingga tidak mudah untuk membedakan perilaku yang lebih perioritas untuk dilakukan terlebih dahulu dari pada sekedar memenuhi keinginannya.

Tipe kepribadian ekstrovert lebih mendominasi terhadap perilaku konsumtif yang dimiliki oleh para subjek. Sehingga anak TKI/TKW yang berusia remaja memiliki kecenderungan untuk mengikuti perubahan yang dilakukan oleh teman-temannya dari pada mendengarkan nasehat yang diberikan oleh keluarganya, terutama orang tua. Subjek dalam penelitian ini menunjukkan cukup banyak memiliki kecenderungan dalam kepribadian ekstrovert, sehingga para anak TKI/TKW memiliki kecenderungan untuk mudah dipengaruhi oleh lingkungannya. Jadi, berdasarkan penelitian ini menunjukkan bahwa para subjek memiliki kecenderungan kepribadian ekstrovert dengan perilaku konsumtif, sehingga perilaku konsumtif terjadi pada anak- anak yang ditinggal bekerja menjadi TKI/TKW di Kecamatan Bandung Tulungagung karena kurangnya perhatian dari orang, sehingga para anak TKI/TKW memiliki kecenderungan untuk meniru perilaku yang dilakukan oleh teman-temannya.

\section{SIMPULAN}

Berdasarkan Hasil Uji Hipotesis dengan menggunakan analisis NonParametric Kendall dapat disimpulkan bahwa H1 terdapat korelasi negatif antara pola asuh permisif dengan perilaku konsumtif pada anak TKI/TKW di Kecamatan Bandung, Tulungagung. Hal ini menunjukkan bahwa tidak ada hubungan yang dapat mempengaruhi antara pola asuh permisif terhadap perilaku konsumtif pada anak TKI/TKW di kecamatan Bandung Tulungagung. Karena pola asuh yang permisif lebih banyak mempengaruhi tugas perkembangan dari tingkat akademis siswa dan kemampuan bersosial, daripada perilaku konsumtif.

Hipotesis pertama terdapat hubungan yang signifkan antara kepribadian ekstrovert dengan perilaku konsumtif pada anak TKI di Kecamatan Bandung, Tulungagung. Tipe kepribadian ekstrovert yang dimiliki oleh para subjek, terbanyak berada di 
kategori sedang, hal ini menunjukkan bahwa anak-anak yang berasal dari kacamatan Bandung Tulungagung memiliki kecenderungan memiliki kepribadian ekstrovert, hanya 16 anak berada dikategori kecenderungan dan tinggi.

Berdasarkan hasil penelitian yang telah dilakukan, mengindikasikan bahwa pola asuh permisif dan kepribadian ekstrovert dengan pola asuh permisif pada anak TKI/TKW memiliki korelasi yang signifikan. Maka dari itu, peneliti memberi saran kepada beberapa pihak, diantaranya:

Bagi partisipan penelitian, adanya hubungan antara kepribadian ekstrovert dengan perilaku konsumtif. Sehingga peneliti memberi saran terhadap subjek agar subjek lebih mau terbuka dengan keluarga, terutama kedua orang tua, agar anak lebih mengikuti nasehat orang tua dari pada nasehat teman-temannya.

Membiasakan diri untuk menyisihkan uang saku yang diberikan untuk ditabung, sehingga dapat mengendalikan diri terhadap barangbarang yang kurang memiliki bermanfaat bagi subjek. Dan memiliki kesadaran bahwa orang tua telah bekerja keras untuk memenuhi kebutuhannya, sehingga lebih memiliki tanggung jawab terhadap diri sendiri.

Bagi Orang Tua, diharapkan untuk dapat meluangkan waktu agar anak menjadi lebih dekat dengan keluarga dari pada teman-temannya. Sehingga orang tua tetap menjadi role model ketika anak beranjak remaja. Lebih banyak memberikan perhatian dan kasih sayang dari pada pemenuhan materi, agar anak merasa tidak terabaikan oleh orang tuanya. Selain itu, ketika orang tua cenderung memberikan keleluasaan dalam melakukan segala hal tetapi sebagai orang tua harus tetap memberikan aturan yang jelas kepada anak, agar anak lebih dapat bertanggung jawab terhadap dirinya sendiri.

Bagi peneliti berikutnya, sebaiknya peneliti membandingkan antara perilaku konsumtif orang tua yang bekerja sebagai TKI/TKW dengan perilaku konsumtif anak yang orang tua bekerja di sekitar tempat tinggal.

\section{DAFTAR PUSTAKA}

Alwisol (2008) Psikologi Kepribadian Edisi Revisi. Malang. UMM Pers

Ancok, D. (1995). Nuansa Psikologi Pembangunan. Yogyakarta: Pustaka Pelajar.

Arikunto, S. (2006) Prosedur Penelitian Suatu Pendekatan Praktik. Jakarta: Rinekan Cipta

Arikunto, S. (2006). Dasar-dasar Statistik. Bandung : Alfabeta

Azwar, S. (2003) Realibilitas dan Validitas. Yogyakarta: Pustaka Belajar

Azwar, S. (2012) Penyusunan Skala Psikologi. Yogyakarta: Pustaka Pelajar

BKKBN (2013). Menjadi orang tua hebat dalam mengasuh anak, bahan penyuluhan bina keluarga balita bagi kader

Desmita. (2005) Psikologi Perkembangan. Bandung: PT Remaja Rosdakarya

Feist, J. \& Feist, G. J. (2009). Theories of Personalities. New York: The McGraw- Hill Companies.

Fromm (1995) Erich Fromm The Sane Society. New York: Fawcett World Library

Hadi, S. (2000). SPS-2000 (Seri Program Statistik-Versi 2000): Manual SPS Paket 
Hotpascaman, (2008). Hubungan antara perilaku konsumtif dengan konformitas pada remaja. SUMUT: Universitas Sumatera Utara

Hurlock, E. B (1997) Psikologi Perkembangan. Jakarta: Erlangga

Hurlock E. (2015) Psikologi Perkembangan Suatu Pendekatan Sepanjang Rentang Kehidupan. Jakarta: Erlangga

Konsumerisme (2008). http://www.freewebs.com/kolektif bunga/konsumerisme.htm

Kusumaningrum, A. (2007). Hubungan Konformitas dengan Perilaku Konsumtif Terhadap Produk Fashion Pada Remaja Putri. Skripsi (tidak diterbitkan). Yogyakarta: Fakultas Psikologi UGM.

Lubis. Y. (1987). Perilaku Konsumtil: Antara Gengsi dan Kenyataan. Jakarta: Gadis.

Mangkunegara, A. P. (2005). Psikologi Konsumen Edisi Revisi. Bandung: PT. Refika Aditama Midi. Yogyakarta: Gadjah Mada University Press

Naiboh, F (2011). Tesis "Pengaruh Pola Asuh Orang Tua Terhadap Kesehatan Remaja pada Keluarga Batak Toba di Kecamatan Pengururan Kabupaten Samosir".Medan: Universitas Sumatra Utara

Pravitaasari, T (2012). Pengaruh Persepsi Pola Asuh Permisif Orang Tua Terhadap Perilaku Membolos. Educational Psychology Journal, Journal UNNES

Rahman, Ulfiani, dkk (2015) Hubungan Antara Pola Asuh Permisif Orang Tua dan Kecemasan Emosional Siswa dengan Hasil Belajar
Matematika Siswa. Auladuna, Vol. 2 No. 1 Juni 2015: 116-130 116. UIN Alauddin Makassar

Santrock, J.W. (2003) Adolesence. Perkembangan Remaja. Jakarta: Erlangga

Sarwono. S, (2000). Psikologi Remaja. Jakarta: PT Raja Grafindo Persada

Sarwono. S, (1993). Teori-teori psikologi sosial. Jakarta: CV. Rajawali

Siwi, W. dkk (2006) Perbedaan Kosep Diri Antara Remaja Akhir Yang Mempersepsi Pola Asuh Orang Tua Authoritaria, Permissive, dan Authoritative. Jurnal Psikologi Vol.4.No.2, Desember 2006. Jakarta: Universitas Indonusa Esa Unggul

Sumartono (2002). Terperangkap dalam iklan: meneropong imbas pesan iklan televisi. Bandung: penerbit Alfabeta

Suminar, E. (2015) Konsep Diri, Konformitas dan Peilaku Konsumtif pada Remaja. Persona, Jurnal Psikologi Indonesia Mei 2015, vol.4.No.02.,Hal 145-152

Stevi, Ana (2017). Hubungan Pola Asuh Permisif Orang Tua dengan Perilaku Mengkonsumsi Alkohol Pada Anak Remaja di Desa Bulude selatan Kabupaten Talaud. e-journal Keperawatan (eKp) Volume 5 Nomor 1, Februari 2017

Suryabrata, S. (1998). Psikologi Kepribadian. Jakarta: PT Raja Grafindo Persada

Suryabrata, S. (2010). Psikologi Kepribadian. Yogyakarta: Graha Ilmu

Setiadi, N. 2003, "Perilaku Konsumen Konsep dan Implikasi untuk Strategi dan Penelitian Pemasaran”. Jakarta: Kencana. 
Wirawan, S. (1989). Psikologi remaja. Jakarta. CV Rajawali

Widyaningrum, (2016) "Perbedaan Perilaku Konsumtif Ditinjau dari Tipe Kepribadian Pada Siswa Sekolah Menengah Atas” Jurnal Psikologi Teori dan Terapan 2016, Vol. 6, no 2, 102-106, ISSN: 2087-1708

Yusuf, Syamsu, 2007. Psikologi Perkembangan Anak dan Remaja. Bandung: Remaja Rosdakarya 